\title{
FROM THE SHIP'S LOG OF H.M.S.A.S. IMHOFF
}

\section{INTRODUCTION}

The archives of the South African Defence Force include, as silent testimony of the distinguished service rendered during World War II by our embryo navy, the original ship's logs of a number of South African ships which saw service firstly with the young Seaward Defence Force and later with the South African Naval Forces.

The Seaward Defence Force actually came into existence on 15 January 1940 and was merged with the South African Division of the Royal Naval Volunteer Reserve on 1 August 1942 to form the newly established South African Naval Forces, the activities of which, in many cases, extended well beyond the confines of South African waters.

A number of South African vessels in fact saw service, at the request of the British Admiralty, as far afield as the Mediterranean Sea, in which theatre, South Africa eventually had four anti-submarine vessels, eight mine-sweepers and the salvage vessel H.M.S.A.S. Gamtoos.

H.M.S.A.S. Imhoff, a small vessel of 248 tons, was one of the mine-sweepers concerned. She was named after the Governor-General Gustaaf Willem, Baron van Imhoff (1705-1750) who was the Governor-General of Ceylon from 1736 to 1740. and of the Dutch East Indies thereafter. During the last years of his life Baron van Imhoff was a Luitenant-General in the armed forces of the Netherlands Republic. He appears briefly in South African history as the Commissioner-General of the Dutch East India Company who conducted an inspection in the Cape during 1743.

Together with other South African ships, H.M.S.A.S. Imhoff was allocated the task during the earlier part of World War II of clearing mines along parts of the coastline of the Mediterranean Sea - a duty which persisted after 31 July 1942 when the Seaward Defence Force became merged into the newly established South African Naval Forces.

The very gallant but repetitive and often, tedious duties and exploits of the South Africans who manned these little ships, both in South African and Middle East waters during World War II, have not always received the measure of attention they so richly deserve.

Many of the officers and ratings were little more than youths whose sea experience extended back no further than the beginning of World War II. Admiral H. H. Biermann, S.S.A., O.B.E., the present Commandant-General of the South African Defence Force, was one of those who, as a young officer, joined the Seaward Defence Force as a Lieutenant on 15 January 1940.

It is indeed a tribute to the growing power of South Africa as a nation, that both the men and the ships that were required by her naval forces were forthcoming within a few months of the outbreak of World War II. It is furthermore a remarkable fact that within a year, more than fifty little ships were in commission and fully manned.

Most of these ships were in fact converted whale catchers or trawlers. The whalers, built originally to operate in the waters of the Antartic, were powerful, fussy little ships with a turn of speed necessary to carry out their new tasks.

It was in May 1941 that the South African Government agreed to the proposal that eight "L.L." mine-sweepers (i.e. the technical title of ships equipped to deal 
with magnetic and acoustic mines) be attached to the Royal Navy for service in the Mediterranean. These included H.M.S.A.S. Imhoff which had been taken over by the Union Government from her desirious owners, Messrs. Kergeulen S. and W. Company on 26 April 1941. This ship first came into service for passage to the Middle East during June 1941 and was thereafter converted to an L.L. minesweeper at Haifa.

Earlier, during April 1941, work had been carried out on her by Messrs. Jameson Welding Works and Louw and Halvorsen of Cape Town. This consisted mainly of the removal of whaling gear and the provision of crew accommodation to enable the vessel to proceed to Haifa for final conversion. As already stated the ship had a tonnage of 248 and a horsepower rating of 750 . She was an oil burner and when commissioned in 1942 was fifteen years old, making her the oldest of the South African ships in the Middle East.

The following extracts from the ship's log will, it is hoped, serve a two-fold purpose, namely to acquain $i$ the reader with a small but important aspect of our naval history while allowing him to get a glimpse of but one facet of the most inieresting naval career of our present Commandant-General, Admiral H. H. Biermann, S.S.A., O.B.E.

\section{1}

\section{FROM DURBAN TO HAIFA. FITTED OUT.}

H.M.S.A.S. Imhoff sailed from Durban under Royal Navy orders in July 1941 and arrived at Port Said on 27 August. Having being degaussed (i.e. demagnetised), H.M.S.A.S. Imhoff was sent to Haifa for fiting out. As this was to take until the end of the year it was arranged for the personnel to be given various training courses. On recommissioning Lieutenant $\mathrm{H}$. H. Biermaan took over command.

Commissioning day for H.M.S.A.S. Imhoff was on 28 February 1942. At this time she was still in Haifa. The hands joined the ship and were employed on such tasks as stowing gear, mounting guns and taking aboard fresh provisions, blankets and mattresses. Also aboard the ship were a number of workmen who were finishing ofi construction work. Imhoff was also secured to a buoy for the purpose of swinging the compasses.

\section{2 \\ FROM HAIFA TO BEIRUT AND ALEXANDRIA}

On 1 March H.M.S.A.S. Imhoff proceeded to sea from Haifa bound for Beirut. Shortly after slipping her moorings, action stations were sounded and all guns were tested and found to be satisfactory. By 1230 H.M.S.A.S. Imhoff was abean of Saida and at 1545 hours entered the harbour at Beirut where she made fast alongside H.M.S.A.S. Gribb. The next day H.M.S.A.S. Imhoff made an unsuccessful attempt to tow H.M.S.A.S. Treen off the slip in Beirut harbour. During these operations the tow rope fouled H.M.S.A.S. Imhoff's screw and she drifted onto a barque causing slight damage. The towing attempts were abandoned at midday.

While H.M.S.A.S. Imhoff stood by on 3 March to leave for towing operations the crew were employed in cleaning the guns, painting and making canvas gun covers. 
In the afternoon the order was given that towing was postponed. Painting and the making of gun covers continued the next day. At 1130 hours H.M.S.A.S. Imhoff cast off and proceeded to the slip once more to tow H.M.S.A.S. Treern. Towing was completed in the afternoon with H.M.S.A.S. Imhoff unable to move H.M.S.A.S. Treern. After slipping the tow line H.M.S.A.S. Imhoff berthed alongside H.M.S.A.S. Seksern.

The morning of 5 March was occupied in preparing the ship for sea. In the afternoon, after swinging the compasses, H.M.S.A.S. Imhoff joined H.M.S.A.S. Seksern, shaped course and set sail for Alexandria. At 1700 hours the guns were tested. At midnight a moderate wind was blowing, there was a moderate sea and swell and the vessel was pitching. By 0400 hours the next morning weather conditions had deteriorated considerably and it was raining hard. The sea was "confused" and the ship was rolling heavily. At 0800 hours the weather was still poor and thirty minutes later speed was reduced. During the morning the starboard trunking for the LL tail broke off. Shortly after 1400 hours H.M.S.A.S. Imhoff was abeam of Gaza and four hours later she sailed into rain squalls. By 2000 hours there was only an occasional shower but by midnight conditions had improved.

The starboard trunking of the L.L. trough was lashed on the morning of 7 March. At nine o'clock H.M.S.A.S. Imhoff picked up the outer channel of Port Said and altered course. She reached the end of the channel at 1045 hours and then made another course alteration to follow H.M.S.A.S. Seksern. Weather conditions were good again by midday. An increase in speed was ordered at 0115 hours on the morning of the 8th and three hours later H.M.S.A.S. Imhoff was sailing in calm seas with the weather fine and clear.

At 0500 hours a report was sent to the commander of the convoy of which H.M.S.A.S. Imhoff was a part, that H.M.S.A.S. Seksern was sailing an unsafe course and twenty minutes later a signal was sent to H.M.S.A.S. Seksern informing her that she had a compass error. H.M.S.A.S. Seksern was again signalled about the compass error at 0545 hours. Shortly after six o'clock H.M.S.A.S. Imhoff touched a submerged object and altered course. A single aircraft was sighted at 0720 hours and action stations were ordered. Just after nine o'clock all clocks were retarded one hour. At about 1000 hours H.M.S.A.S. Imhoff berthed alongside H.M.S.A.S. Seksern at No. 41 Quay in the harbour at Alexandria.

March the 12th saw H.M.S.A.S. Imhoff proceeding to the ports and lights quay for refitting. The anchor cable was taken ashore for surveying and annealing. The decks were caulked and the L.L. overhauled. Strips were bolted to the winch drum while the hands cleaned the guns. Stores as well as a Carley float were loaded aboard on the 13th. Refitting continued on the 14th. This included the mounting of an extra compass and an Oerlikon gun aft. The anchor cable was returned after being surveyed.

\section{3 \\ FROM ALEXANDRIA TO PORT SAID}

After taking in stores on the morning of the 17th H.M.S.A.S. Imhoff was placed on thirty minutes sailing notice. At 1515 hours she cast off and proceeded to sea in fine weather conditions. She was headed for Port Said. After sailing all night and the next morning H.M.S.A.S. Imhoff made fast alongside H.M.S.A.S. Seksern in the Navy Dock at Port Said at 1700. H.M.S.A.S. Imhoff then went into the dry dock where her hull was scraped and the propellor shaft glands were overhauled on the 20th. Refitting continued until the 23 rd when workmen came aboard for 
further repairs to the winch and the strengthening of the L.L. troughs. At midnight on 31st March all clocks were advanced one hour in accordance with Egyptian Summer Time.

On 2 April 1942 H.M.S.A.S. Imhoff weighed anchor at 1620 hours and in company of H.M.S.A.S. Southern Sea, H.M.S.A.S. Treern and two merchant ships left Port Said for Alexandria at 1700 hours. H.M.S.A.S. Southern Sea was in command of the convoy. Shortly after 0200 hours the next morning the leading ship fired blue and red flares. H.M.S.A.S. Imhoff changed course to port immediately and reduced speed. Full speed ahead was ordered thirty minutes later. Sailing then continued uneventfully until after 1300 hours on 3 April when the convoy formed line ahead for entry into the harbour at Alexandria. H.M.S.A.S. Imhoff berthed at No. 42 Quay. That night there were two air raid alarms but no aircraft were seen or heard and no barrage was put up.

\section{4 \\ AIR RAIDS AT ALEXANDRIA}

At this stage the enemy were only a few minutes by air from Alexandria and raids on the port, including mine-dropping, increased greatly in intensity. About twenty-five parachute mines were seen to fall in the Alexandria area during April and May. Some exploded on the shore on impact or in the water of their own accord soon after being laid. The remainder were sufficiently obstinate to keep the L.L.'s fully occupied for some months and others were never detonated. This resulted in the South African vessels being fully employed both at Alexandria and Haifa - the alternative naval base in Palestine.

The 4th and 5th of April were spent carrying out routine tasks. The morning of 6 April saw some anxious moments for the docks at Alexandria. H.M.S.A.S. Imhoff had just completed streaming her L.L. when there was an air raid alarm. Aircraft were seen and the anti-aircraft guns opened fire. The all clear was given after thirty minutes. H.M.S.A.S. Imhoff's gun crews proceeded ashore later in the day for gunnery instruction.

Enemy aircraft were active again on the 7th. The alarm was sounded for the first time at 0345. An intensive barrage was put up. Numerous aircraft were observed and they managed to drop several bombs in the harbour area, the concussion of which was felt on board H.M.S.A.S. Imhoff. Two more air raid warnings followed at 1000 hours and 1030 hours but no bombs were dropped. In the afternoon H:M.S.A.S. Imhoff made fast alongside H.M.S. Eridge as plug ship.

Alexandria experienced further air raids on 8 April, the first of which took place just before four o'clock in the morning. Several bombs as well as numerous flares were again dropped in the harbour area and an intensive barrage was put up. The ward room doors, some bridge fittings and a telegraph and cable box aboard H.M.S.A.S. Imhoff were damaged from bomb blast. Three more air raid warnings were sounded during the morning but no aircraft were sighted. Amid all this the crew members of H.M.S.A.S. Imhoff still had to undergo gunnery instruction. On 9 April, a similar day was experienced. The next day there was no leave for the crew as H.M.S.A.S. Imhoff was duty ship for the night. A party of workmen went aboard during the day to repair the damage caused to the bridge on the 8th.

After some sweeping together with H.M.S.A.S. Gribb on the morning of 20 April, H.M.S.A.S. Imhoff returned to harbour. The crew were later marched to No. 44 Quay and fallen in for inspection by H.R.H. the Duke of Gloucester. 


\section{5 \\ MINE SPOTTING AND MINE-SWEEPING}

H.M.S.A.S. Imhoff did not take part in any sweeping activities on Saturday 25 April but at 1845 hours she proceeded to a minespotting position where she was anchored and the watch set for the night. No barrage was put up during an air raid alarm which was sounded at 2330 hours. The all clear was given shortly after midnight.

Sweeping was resumed by H.M.S.A.S. Imhoff on the 27th in company with H.M.S.A.S. Gribb. The vessel was then berthed at No. 44 Quay and a start was made with the fitting of ventilation fans. Routine sweeping commenced the day's tasks on 28 April and on completion H.M.S.A.S. Imhoff was berthed. More work was done on the ventilating fans and the L.L. switchboards during the morning. At 2145 hours that night enemy bombers were responsible for more activity. Bombs were dropped in the vicinity of the berth setting fire to an ammunition truck and a shed alongside the ship. The ammunition started exploding and H.M.S.A.S. Imhoff was shifted hurriedly owing to the danger of the ship also catching fire. No damage was sustained on board.

Next day the debris from the air raid was cleared from the ship and work continued on the fitting of the ventilation fans and the L.L. switchboards. That night H.M.S.A.S. Imhoff moved alongside H.M.S. Hero as plug ship. An air raid alarm was sounded at 2215 hours but no barrage was put up.

On Saturday 2 May, H.M.S.A.S. Imhoff had to return to her berth owing to a defect in the S.A. hammer after she had set out for some sweeping. This was repaired and she cast off again. That night two air raid warnings were sounded but no aircraft passed overhead.

Following the calm of Sunday an air raid warning was sounded at 0400 hours on Monday the 4th. A heavy barrage was put up and ninety minutes later the all clear was given. On 5 May, H.M.S.A.S. Imhoff did some more sweeping. Lieutenant W. D. de la Bat van Alphen joined the ship's company in the morning as additional officer. Further changes in the complement of ratings of the ship took place on 7 May.

On 13 May, H.M.S.A.S. Imhoff was berthed at No. 40 Quay where she was to stay until the end of that month undergoing a boiler cleaning and the fitting of an additional generator and batteries. Various deck defects were also repaired. For the crew it was painting and general maintenance on board the ship and the gunners had a few shoots.

\section{6 INSPECTION DAY. SWEEPING OPERATIONS CONTINUED}

The 16th of May was an important day for the ship and its crew. At 1015 hours the hands were fallen in for inspection by Field-Marshall J. C. Smuts. The FieldMarshall was accompanied by the Chief of the General Staff, Lieutenant-General Sir Pierre van Ryneveld. Their visit was part of an inspection tour of the officers, men and ships of the Seaward Defence Force in the Mediterranean. After inspecting the men on parade the party also went on board H.M.S.A.S. Imhoff to see how the work being carried out was progressing. 
On Sunday the 24th a church service was conducted in the forward messdeck. At midnight there was an air raid warning but nothing happened and thirty minutes later the all clear was given. H.M.S.A.S. Imhoff was moved to No. 48 Quay on the 29 th where she was prepared for fumigation. The crew were drafted ashore to the United Forces Hostel. Fumigation continued on the 30th and the crew rejoined the ship on the morning of the 31st. H.M.S.A.S. Boksburg came alongside at 0900 hours to supply H.M.S.A.S. Imhoff with steam. On 8 June she set out for sweeping operations in company with H.M.S.A.S. Gribb. A fault developed in her sweeping gear and she was relieved by H.M.S.A.S. Boksburg.

The 9 th and 10th were spent cleaning up the ship and on the 11th H.M.S.A.S. Imhoff was the dress ship on the occasion of the birthday of the King. That night she was employed in mine spotting.

On Monday the 15th workmen went aboard to effect repairs to the L.L. trails which had become waterlogged. A party of officers went on board the ship the next day to observe a test sweep. That night, while on mine spotting duties, gun flashes were observed in the vicinity of Ras el Tin. H.M.S.A.S. Imhoff's gun crews were placed on the alert but nothing further was observed and the weapons were secured.

\section{7 \\ STEAMING ORDERS RECEIVED AND CANCELLED}

On the morning of 29 June there was an air raid warning. Later that morning steaming orders were received and all leave was cancelled until further notice. The situation on land had become so critical since the fall of Tobruk on the 21st that, as part of the evacuation plan, the ships were ordered to embark minesweeping stores - H.M.S.A.S. Imhoff also doing her share. The afternoon was taken up by minesweeping but this work had to be abandoned owing to the arrival of a convoy. Another air raid warning was sounded at 2240 hours and the gun crews took up stations. Two mines were seen to fall near the swept channel to the harbour and their position was noted and reported.

Preparations were made early next morning for sweeping but this could not be done because the batteries of the sweeping gear were defective. H.M.S.A.S. Imhoff then entered the harbour and more stores were taken on board. During the afternoon it became clear that the steaming orders were no longer necessary and they were cancelled.

The enemy reached El Alamein on 1 July 1942 with the result that air raid alarms were frequent early in the month. The first of these was sounded at 0120 hours on the 1st but no barrage was put up. Later that morning the stores taken on board H.M.S.A.S. Imhoff following the receipt of the steaming orders were returned to the quay. A light barrage was put up during an air raid early on the 2 nd but no aircraft were seen. Immediately afterwards H.M.S.A.S. Imhoff weighed anchor and began sweeping in company with H.M.S.A.S. Boksburg. During these operations the hammer "A" frame and chair were carried away by heavy seas and H.M.S.A.S. Imhoff then returned to harbour. More stores were returned to land on the 4th. At midnight there was the inevitable air raid during which H.M.S.A.S. Imhoff's crew observed a fire ashore from where they were anchored in a minespotting position. The next three days were spent in harbour. 
Early on Wednesday morning the watch reported that several flares were dropped over the aerodrome. The day was spent in harbour and while on mine spotting that night the anti-aircraft guns opened fire but nothing was observed. On 9 July there were two air raid warnings. The first was early in the morning but nothing was observed and the second came at 2015 hours that night. Two aircraft were observed overhead and they were given a few bursts of anti-aircraft fire. A party of workmen went aboard on the 15th to fit a new "A" frame and hammer. This work was completed on the 18th. An additional ammunition box was also fitted on the boat deck.

\section{8}

\section{THE BIRTH OF THE SOUTH AFRICAN NAVAL FORCES (S.A.N.F.). COMMAND TAKEN OVER}

July 20th was marked by a conference held at far away Defence Headquarters in Pretoria at which it was decided to amalgamate the Seaward Defence Force and the Royal Naval Volunteer Reserve (S.A. Division) to form the South African Naval Naval Forces. This decision was published in the Government Gazette on 31 July 1942 and came into effest on 1 August 1942.

Except for an air raid warning on the 26th, H.M.S.A.S. Imhoff had a quiet time until the 27 th. The enemy was active on $3 \mathrm{July}$, with two early morning raids.

The first half of August was again a quiet period for H.M.S.A.S. Imhoff and her crew. There was only one air raid and the remainder of the time was taken up mainly by mine spotting and mine-sweeping duties.

On the morning of 21 August the vessel was made fast in the dry dock at Alexandria for a general underwater survey, scraping and painting. After refloating, a boiler party went aboard to clean and refit. This work continued until the 30th and the next day mine-sweeping was resumed.

The month of September 1942 was marked by a change in the command of H.M.S.A.S. Imhoff. Lieutenant Gilbert Vallance Webb took over command from Lieutenant H. H. Biermann.

Lieutenant Webb and other officers continued to operate H.M.S.A.S. Imhoff on various duties in the Mediterranean and Aegean Seas. These tasks included the final clearances of the Gulf of Athens and Candia Bay. On 1 July 1945 H.M.S.A.S. Imhoff sailed from Alexandria for South Africa but her worn out condition caused a series of defects and delayed her arrival at Durban - towed by the frigate H.M.S.A.S. Good Hope for the last 970 miles - until 4 October. $^{3}$

\section{9}

\section{EXPLANATORY NOTES}

1. The South African "L.L." or "Double L" minesweepers carried two magnetic or "L" sweeps and an electrically driven hammer ("S/A" gear) but were not fitted with "M/S" gear for dealing with moored mines. They were armed only with one 20 millimetre Oerlikon, one quadruple 0,5 Vickers and a number of smaller machine-guns. Later a second Oerlikon was mounted in place of the Vickers. 
The LL sweepers were fitted to deal with both magnetically and accoustically operated "ground mines" - the general term for those mines laid on the sea bed, usually by means of aircraft and parachutes. For this type of work which was carried out generally in or near the ports by independent vessels, smaller, slower and less seaworthy ships could be accepted than for $\mathrm{A} / \mathrm{S}$ escort duties. In addition their special equipment added a considerable amount of extra topweight so that they could be given only a very light gun armament.

2. Minespotting was a secondary but important duty. Every night, when air raids were prevalent, one or two LL's anchored in the approaches and kept a sharp lookout for falling parachutes to which the mines were attached. Observation posts on land did the same and the positions of dropped mines were plotted by cross-bearings so that shipping could be kept clear of the area until it had been swept.

3. Sweeping was usually a lengthy operation as most, if not all, of the mines were of the "clicker" type, their firing mechanism being set so that it had to be actuated an unknown number of times, by magnetic or accoustic means, before it fired the charge. As the crossing of these dangerous areas, deliberately and frequently, was essential for their work, the safety of the L.L. sweepers depended entirely on their being accurately degaussed, i.e. demagnetised.

The firing gear of a magnetic mine consisted of electrical contacts, closed by a compass needle, and sufficiently delicate to be actuated by the near approach of the natural magnetic field produced by a ship. To neutralise this field for the protection of the ship, special circuits were installed on board the vessel through which electric currents of variable strength were passed from the ship's dynamos. As the field was liable to alter in time, and also according to the ship's position on the earth's surface, it had to be measured periodically and the neutralising currents adjusted accordingly. This was done at the degaussing ranges by steaming the ship several times over a line of submerged coils of electric cable connected to a shore station. On shore the ship's magnetic field was depicted accurately on graph form. After several runs and some calculations information was passed to the ship where the appropriate adjustments were made.

The fore and aft component of a ship's magnetism, not conveniently neutralised by degaussing circuits, could be removed by wrapping several electric cables completely round the ship (over and under her) and passing high current through them momentarily. This magnetised the ship in the opposite sense to its original fore and aft magnetic polarity. The current was supplied from storage batteries in an auxiliary vessel placed alongside for the purpose. To control the operation measuring instruments had to be placed under the ship. These were slung from either ropes or permanently installed in boreholes in the sea bed where the ship could be berthed directly over them.

Degaussing and reperming (as the neutralisation of the fore and aft component of the ship's magnetism was referred to) were not merely for local defence but were part of a world wide service for the protection of shipping of all kinds. After being so treated the ship's compasses were usually affected.

H.M.S.A.S. Imhoff's original Commissioning Pennant, which was part of the author's collection of badges and militaria, has been placed in the South African National War Museum in Johannesburg for safe-keeping. 


\section{BIBLIOGRAPHY:}

1. The war at Sea 1939-1945 by Captain S. W. Roskill, D.S.C., R.N. Volumes I to III. Her Majesty's Stationery Office, London, 1954.

2. War in the Southern Oceans $1939-1945$ by L. C. F. Turner, H. R. Gordon-Cumming, O.B.E., R.N. (Ret.) and J. E. Betzler. Oxford University Press, Cape Town, 1961.

3. Cuttings from various newspapers.

4. H.M.S.A.S. Imhoff by Neville Gomm. Article in the "Military History Journal." (Johannesburg). Vol. 1, No. 2, June 1968.

5. S.A.D.F. Archives, Pretoria.

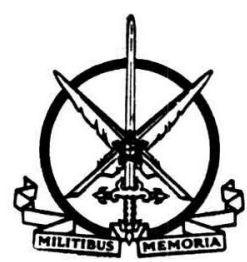

